\title{
PERENCANAAN SEBARAN SARANA PENANGANAN SAMPAH MELALUI PENDEKATAN TIPOLOGI PERMUKIMAN DI KOTA TANGERANG
}

\section{Distribution of Solid-Waste Treatment Facility Planning by Residential Typology Approach in the City of Tangerang}

\author{
Supriyatno1)*, Komarsa Gandasasmita'2), dan Soekmana Soma ${ }^{3)}$ \\ 1) Alumni Program Studi Ilmu Perencanaan Wilayah, Sekolah Pascasarjana IPB, Jl. Raya Darmaga, Gedung Andi \\ Hakim Nasoetion Kampus IPB Darmaga Bogor 16680 \\ 2) Departemen Ilmu Tanah dan Sumberdaya Lahan, Fakultas Pertanian IPB, J1. Meranti Kampus IPB Darmaga \\ Bogor 16680 \\ 3) Pusdiklat, Kementerian Pekerjaan Umum dan Perumahan Rakyat, Jl. Sapta Taruna Raya Komplek PU Pasar \\ Jumat, Jakarta
}

\begin{abstract}
Tangerang as a buffer city for Jakarta has a fairly rapid population growth, about $3 \%$ increment per year. Along with population growth, the amount of waste that must be handled by the government will increase as well. As the largest source of waste, residential or domestic waste needs to be managed as good as possible. Based on sustainable waste management spirit, it needs to know the character or behavior of people in their households garbage handling to plan the kind of solid-waste facility in each residential types. Objectives of this study are to identify the typology of residential in the city of Tangerang by the characteristics of residential and its communities in domestic waste handling and to assign the solid-waste facility based on each typology priority. Identifying the residential typology use spatial analysis to impose its physical characteristics and combine with descriptive analysis to specify the community characteristics for each residential, and to assign the needs of solid-waste facility by the priority level that appropriate for each residential types is used AHP and MCDM-TOPSIS. The combination of physical characteristics and community characteristics classify residential into 12 (twelve) typology, and the result of AHP and MCDM-TOPSIS analysis create 6 (six) residential groups with different level of priority of solid-waste facility based on the $3 R$ general guidelines by the Ministry of Public Works.
\end{abstract}

Keywords: AHP, MCDM-TOPSIS, residential typology, solid-waste facility

\begin{abstract}
ABSTRAK
Tangerang sebagai kota penyangga Jakarta memiliki pertumbuhan penduduk yang cukup pesat, sekitar $3 \%$ per tahun. Seiring dengan pertumbuhan penduduk, jumlah sampah yang harus ditangani oleh pemerintah akan meningkat juga. Sebagai sumber sampah terbesar, sampah domestik dari permukiman perlu dikelola sebaik-baiknya. Dengan semangat pengelolaan sampah yang berkelanjutan perlu direncanakan jenis sarana persampahan di setiap jenis permukiman berdasarkan karakter atau perilaku orang dalam penanganan sampah rumah tangga mereka. Tujuan penelitian ini adalah mengidentifikasi tipologi permukiman di Kota Tangerang menurut karakteristik perumahan dan masyarakatnya dalam penanganan limbah domestik serta menentukan kebutuhan sarana persampahan berdasarkan prioritas pada setiap tipologinya. Dalam mengidentifikasi tipologi perumahan digunakan analisis spasial untuk menentukan karakteristik fisik dan dikombinasikan dengan analisis deskriptif untuk mengetahui karakteristik masyarakat, sedangkan untuk menentukan kebutuhan sarana persampahan yang sesuai di setiap jenis perumahan berdasarkan prioritasnya digunakan analisis AHP dan MCDM-TOPSIS. Kombinasi antara karakteristik fisik dan karakteristik masyarakat menghasilkan 12 (dua belas) tipologi permukiman, sedangkan hasil dari analisis AHP dan MCDM-TOPSIS menghasilkan 6 kelompok permukiman yang mempunyai prioritas kebutuhan sarana persampahan yang berbeda-beda berdasarkan pedoman umum 3R di kawasan permukiman
\end{abstract}

Kata kunci: AHP, MCDM-TOPSIS, tipologi permukiman, sarana persampahan

\section{PENDAHULUAN}

Perkembangan kota yang pesat menyebabkan semakin bertambahnya jumlah penduduk di kota tersebut, baik karena daya tarik kesempatan kerja maupun karena kualitas dan kuantitas sarana kota yang makin meningkat, sehingga akan menambah produksi dan volume sampah yang berbanding lurus dengan perkembangan kota dan pertambahan jumlah penduduk. Peningkatan laju timbunan sampah perkotaan yang tidak diikuti dengan ketersediaan prasarana dan sarana persampahan yang memadai, berdampak pada pencemaran lingkungan yang selalu meningkat dari tahun ke tahun. Dengan selalu mengandalkan pola kumpul-angkut-buang, maka beban pencemaran akan selalu menumpuk di lokasi Tempat Pembuangan Akhir (TPA). 
Berdasarkan hasil laporan Rencana Pengelolaan Sampah Kota Tangerang Tahun 2006-2010, yang dilakukan konsultan JABODETABEK Waste Management Corporation (JWMC) melalui proyek Western Java Environmental Management Project (WJEMP) oleh Direktorat Jenderal Pembangunan Perkotaan dan Pedesaan pada tahun 2005, didapatkan bahwa sumber sampah terbesar di Kota Tangerang berasal dari permukiman yaitu sebesar $91.90 \%$ dari total sampah yang dihasilkan setiap harinya (JWMC, 2005).

Dalam rangka mendorong masyarakat untuk dapat mengelola sampah melalui konsep Reduce, Reuse dan Recycle (3R), Peraturan Pemerintah Nomor 81 Tahun 2012 tentang Pengelolaan Sampah Rumah Tangga dan Sampah Sejenis Sampah Rumah Tangga (Pemerintah Republik Indonesia, 2012) menyatakan bahwa kewajiban dalam memfasilitasi sarana penanganan sampah merupakan tanggung jawab pengelola kawasan permukiman untuk skala kawasan dan pemerintah daerah untuk skala kota.

Dengan dasar pertimbangan tersebut, pendekatan tipologi permukiman dapat dijadikan dasar bagi perumusan sistem pengelolaan sampah permukiman berbasis masyarakat. Dengan mempertimbangkan aspek keberagaman dalam permukiman di perkotaan, diharapkan penerimaan dan partisipasi masyarakat dapat optimal. Dalam penelitian ini, identifikasi kondisi fisik permukiman dan karakteristik masyarakat pada tiap tipologi permukiman menjadi penting untuk menentukan prioritas kebutuhan jenis sarana prasarana pengelolaan sampah yang sesuai dengan karakter permukiman dan masyarakatnya sehingga dapat lebih berdaya guna dalam menangani sampah sejak dari sumbernya.

\section{Ruang Lingkup Penelitian}

Pada penelitian ini, permukiman yang menjadi sasaran studi adalah permukiman teratur dengan tujuan untuk mendapatkan homogenitas masyarakatnya, dengan asumsi yang dibangun adalah keteraturan kawasan mempengaruhi homogenitas karakter masyarakat. Sarana pengelolaan sampah yang menjadi obyek studi adalah sarana 3R (komposter dan bank sampah), TPST (Tempat Pengelolaan Sampah Terpadu), dan kontainer sampah, karena sarana itulah yang selama ini disediakan oleh Dinas Kebersihan dan Pertamanan Kota Tangerang.

\section{BAHAN DAN METODE}

Penelitian dilaksanakan di Kota Tangerang. Jenis data yang digunakan terdiri dari data primer dan data sekunder. Data primer diperoleh melalui wawancara dengan perwakilan pejabat Dinas Kebersihan dan Pertamanan Kota Tangerang serta perwakilan masyarakat oleh ketua RW dan kader lingkungan, dengan pertimbangan penguasaan kondisi pengelolaan sampah secara umum dan/atau secara lokal di masing-masing permukiman sekaligus karakter sebagian besar masyarakat di lingkungannya masing-masing. Data sekunder diperoleh dari instansi-instansi terkait, antara lain dari Dinas Kebersihan dan Pertamanan, Dinas Tata Kota, Kantor Penelitian dan Pengembangan Statistik, serta instansiinstansi lainnya yang terkait. Analisis menggunakan
Microsoft Excel add-ins Sanna dan software pengolah peta ArcGIS.

\section{Identifikasi Tipologi Permukiman}

Untuk mengidentifikasi tipologi permukiman digunakan gabungan antara analisis spasial untuk mengetahui karakteristik fisik suatu permukiman dan analisis deskriptif kualitatif untuk mengetahui karakter masyarakatnya.

\section{Analisis spasial}

Analisis spasial untuk identifikasi tipologi permukiman dilakukan dengan mengggunakan metode interpretasi visual citra satelit untuk mengklasifikasikan permukiman. Faktor-faktor yang dijadikan dasar klasifikasi antara lain keteraturan kawasan, kepadatan ruang, luas bangunan (Saribanon et al., 2007), ketersediaan lahan kosong atau lahan terbuka, dan aksesibilitasnya.

Intepretasi visual dilakukan dengan digitasi on screen menggunakan software SIG untuk mengklasifikasikan permukiman dalam bentuk poligon-poligon berdasarkan ciri-ciri visualnya, dimana faktor kepadatan ruang serta luas bangunan digunakan untuk membedakan kelompok permukiman (Tabel 1), faktor ketersediaan lahan kosong dibedakan sebagai tersedia atau tidak tersedia (Tabel 2), dan faktor aksesibilitas dibedakan berdasarkan jarak permukiman terhadap jalan arteri dan/ atau jalan kolektor sebagai memadai $(<500 \mathrm{~m})$ atau tidak memadai (>500 m) (Tabel 3). Berdasarkan pedoman umum pengelolaan sampah $3 \mathrm{R}$ berbasis masyarakat di kawasan permukiman (Departemen Pekerjaan Umum, 2008) jarak ideal TPST adalah 500 meter dari jalan protokol yang mempertimbangkan aspek estetika kota dan kemudahan mobilitas truk sampah.

Tabel 1. Kelompok permukiman

\begin{tabular}{ccc}
\hline $\begin{array}{c}\text { Kelompok } \\
\text { Permukiman }\end{array}$ & Kepadatan & Luas Bangunan \\
\hline 1 & Jarang & Besar \\
2 & Rapat & Sedang \\
3 & Jarang & Sedang \\
\hline
\end{tabular}

Tabel 2. Ketersediaan lahan

\begin{tabular}{cc}
\hline Ketersediaan Lahan & Letak \\
\hline T1 & Tengah Poligon \\
T2 & Di luar Poligon \\
TT & Tidak tersedia \\
\hline
\end{tabular}

Tabel 3. Aksesibilitas

\begin{tabular}{cc}
\hline Aksesibilitas & $\begin{array}{c}\text { Jarak dari jalan } \\
\text { arteri/kolektor }\end{array}$ \\
\hline Memadai & $<=500 \mathrm{~m}$ \\
Tidak Memadai & $>500 \mathrm{~m}$ \\
\hline
\end{tabular}

\section{Analisis Deskriptif Kualitatif}

Untuk mendapatkan gambaran karakter masyarakat dalam penanganan sampah, dilakukan analisis deskriptif kualitatif. Analisis ini dilakukan melalui penyebaran kuesioner dan wawancara langsung kepada masyarakat pada masing-masing tipe permukiman, dimana pemilihan 
lokasi dan penentuan jumlah responden menggunakan metode Stratified Random Sampling.

Pemilihan lokasi dilakukan dengan memperhatikan sebaran klasifikasi permukiman hasil analisis sebelumnya berdasarkan wilayah pelayanan sampah Dinas Kebersihan dan Pertamanan, yaitu wilayah barat, tengah dan timur Kota Tangerang. Penentuan jumlah responden mempertimbangkan jumlah dan ukuran dari poligon yang mewakili masing-masing tipe permukiman. Untuk memperoleh gambaran permukiman/ wilayah yang cukup komprehensif, target responden diutamakan tokoh masyarakat (Ketua RW/kader lingkungan).

Lokasi sampel disesuaikan dengan sebaran poligon dari masing-masing tipe menurut wilayah pelayanan sampah DKP dan ditentukan dengan pertimbangan unsur keseimbangan keterwakilan wilayah. Jumlah responden ditentukan berdasarkan ukuran poligon yaitu ukuran kecil diwakili oleh 1 responden, ukuran sedang diwakili 3 responden dan ukuran besar 5 responden. Apabila pada satu tipe permukiman yang sama terdapat ukuran poligon yang sama di dua atau tiga wilayah, maka dipilih lokasi yang tingkat keterwakilannya lebih sedikit dibanding wilayah lain. Hal ini dilakukan untuk mempertahankan tingkat keterwakilan sampel terhadap populasi.

Materi kuesioner dan wawancara disusun dengan berpedoman pada Buku Pedoman Umum 3R Berbasis Masyarakat di Kawasan Permukiman Departemen Pekerjaan Umum yang meliputi aspek pemilahan sampah, partisipasi, penerimaan masyarakat, kesanggupan dan kemauan membayar retribusi, keberadaan kader dan pengelola sampah.

Pada saat menyebarkan kuesioner dan melakukan wawancara, peneliti juga melakukan cek lapangan mengenai kondisi dan status lahan terbuka yang diidentifikasi pada analisis spasial sebelumnya, didapatkan bahwa pada lokasi sampel yang sebelumnya dinyatakan tersedia lahan terbuka, baik di dalam poligon (T1) maupun di luar poligon (T2), ada yang bisa langsung dimanfaatkan untuk lokasi pengelolaan sampah terpadu 3R (TPST) karena merupakan lahan fasos fasum pemerintah Kota Tangerang (TA) dan ada yang tidak bisa langsung dimanfaatkan karena status kepemilikannya masih milik pribadi, milik developer atau milik pemerintah tetapi sudah direncanakan dan/atau sudah dimanfaatkan untuk fasilitasi publik/taman (TB).

Dengan menggabungkan hasil analisis spasial dengan atribut karakter masyarakat hasil kuesioner dan wawancara menggunakan teknik query pada software SIG akan didapatkan tipologi permukiman akhir yang disusun dalam bentuk tabulasi dan dilakukan analisis deskriptif untuk dapat menentukan tipologi permukiman di Kota Tangerang berdasarkan karakter masyarakat dalam menangani sampahnya.

\section{Perumusan Sebaran Sarana Persampahan}

Untuk merumuskan sebaran sarana persampahan yang sesuai untuk setiap tipe permukiman digunakan dua alat analisis, yaitu Analytical Hierarchy Process (AHP) dan Multi Criteria Decision Making (MCDM).

\section{Analytical Hierarchy Process (AHP)}

AHP adalah suatu proses analisis yang berhierarki melalui penyusunan prioritas dalam pengambilan keputusan yang mempunyai multi kriteria, dengan mempertimbangkan aspek kualitatif dan kuantitatif untuk mendapatkan keputusan terbaik. AHP didesain untuk menangkap persepsi orang secara rasional mengenai permasalahan tertentu dan menentukan prioritas dari beberapa alternatif berdasarkan kriteria-kriteria yang dibangun. Metode ini dimaksudkan untuk membantu memecahkan masalah kualitatif yang kompleks dengan memakai perhitungan kuantitatif, melalui proses pengekspresian masalah dimaksud dalam kerangka berpikir yang terorganisir, sehingga memungkinkan dilakukannya proses pengambilan keputusan secara efektif (Eriyatno dan Sofyar, 2007). Input utama dalam suatu hierarki AHP adalah persepsi stakeholders dengan pembobotan berdasarkan skala perbandingan (Saaty, 2008). Pada penelitian ini, AHP digunakan untuk mengetahui bobot setiap kriteria yang mempengaruhi penentuan prioritas sarana persampahan pada masingmasing tipe permukiman. Struktur AHP dibangun pada masing-masing hierarki atau level yaitu (level 1) lingkungan, sosial, ekonomi, serta kelembagaan dan (level 2) ketersediaan lahan, aksesibilitas, pemilahan sampah, partisipasi, penerimaan masyarakat, kesanggupan membayar, kemampuan membayar, keberadaan kader serta keberadaan pengelola. Dasar pemilihan kriteria pada level 1 adalah karena merupakan pilar pembangunan berkelanjutan, sedangkan untuk kriteria pada level 2 berdasarkan Pedoman Umum 3R Berbasis Masyarakat di Kawasan Permukiman (Departemen Pekerjaan Umum, 2008).

Responden yang dipilih adalah pihak-pihak yang dianggap pakar atau mengetahui benar tentang pengelolaan sampah dan atau permukiman maupun pihak-pihak yang terlibat langsung dalam pengelolaan sampah, antara lain perwakilan dari Dinas Kebersihan dan Pertamanan, Dinas Pekerjaan Umum, kader persampahan, dan akademisi.

\section{Multi Criteria Decision Making (MCDM)}

Hasil pembobotan masing-masing kriteria dari proses AHP tersebut digunakan untuk pemilihan sarana persampahan berdasarkan prioritas terbaik dari setiap kriteria dengan menggunakan analisis MCDM melalui program tambahan (add-ins/plugins) Sanna pada Microsoft Excel. MCDM merupakan pendekatan yang digunakan untuk mengevaluasi berbagai alternatif berdasarkan banyak kriteria yang tidak dapat dievaluasi dengan pendugaan sederhana atau dengan satu dimensi (Vreeker dalam Postorino dan Pratico, 2012).

Metode MCDM dalam penelitian ini adalah teknik TOPSIS (Technique for Order Performance by Similiarity to Ideal Solution). TOPSIS merupakan teknik untuk menganalisis, membandingkan dan mengurutkan banyak alternatif, berdasarkan kriteriakriteria yang ditentukan sebelumnya pada tahapan analisis AHP, sehingga didapatkan prioritas untuk dapat dilaksanakan atau diimplementasikan (Shih et al., 2007). Penggunaan TOPSIS dalam metode pengambilan keputusan multi-kriteria (MCDM) pertama kali diperkenalkan oleh Hwang dan Yoon (1981). 
Analisis MCDM-TOPSIS dilakukan dengan mengurutkan prioritas sarana persampahan untuk setiap kriteria sesuai karakteristik lingkungan dan masyarakat pada masing-masing tipologi permukiman, yaitu antara lain: ketersediaan lahan dengan status milik pemerintah atau pihak lainnya dengan surat persetujuan penggunaan, lahan tersebut telah dimanfaatkan/difungsikan sebagai tempat pembuangan sampah atau berada di area yang rencana pemanfaatan untuk fasilitas umum/taman cukup rendah, mempunyai aksesibilitas yang memadai untuk mobilisasi gerobak atau motor sampah, mempunyai program lingkungan berbasis masyarakat, ada tokoh masyarakat yang memiliki wawasan lingkungan cukup kuat, penerimaan masyarakat terhadap program $3 \mathrm{R}$, bersedia membayar retribusi sampah, memiliki pengelola kebersihan/sampah (Departemen Pekerjaan Umum, 2008).

\section{HASIL DAN PEMBAHASAN}

\section{Tipologi Permukiman}

Dari penggalian data, diperoleh 3 (tiga) kelompok permukiman, 3 (tiga) jenis ketersediaan lahan dan 2 (dua) macam aksesibilitas yang dikombinasikan sehingga mendapatkan 12 tipe permukiman yang menggambarkan kondisi fisik lingkungan yang spesifik seperti yang tercantum pada Tabel 4.

Tabel 4. Tipe permukiman

\begin{tabular}{ccccc}
\hline Tipe Permukiman & $\begin{array}{c}\text { Kelompok } \\
\text { Permukim }\end{array}$ & $\begin{array}{c}\text { Ketersediaan } \\
\text { Lahan }\end{array}$ & Aksesibilitas & $\begin{array}{c}\text { Jumlah } \\
\text { poligon }\end{array}$ \\
\hline a & 1 & Tersedia 1 & Memadai & 28 \\
b & 2 & Tersedia 1 & Memadai & 51 \\
c & 3 & Tersedia 1 & Memadai & 7 \\
d & 1 & Tersedia 2 & Memadai & 1 \\
e & 2 & Tersedia 2 & Memadai & 19 \\
f & 3 & Tersedia 2 & Memadai & 2 \\
g & 1 & Tersedia 1 & Tidak Memadai & 3 \\
h & 2 & Tersedia 1 & Tidak Memadai & 5 \\
i & 3 & Tersedia 1 & Tidak Memadai & 2 \\
j & 1 & Tersedia 2 & Tidak Memadai & 1 \\
k & 2 & Tersedia 2 & Tidak Memadai & 5 \\
1 & 2 & Tidak Tersedia & Memadai & 2 \\
\hline
\end{tabular}

Tabel 5. Pembagian lokasi sampel

\begin{tabular}{|c|c|c|c|c|c|c|c|c|}
\hline \multirow{3}{*}{ Tipe Permukiman } & \multicolumn{7}{|c|}{ Jumlah Poligon } & \multirow{3}{*}{ TOTAL } \\
\hline & \multicolumn{3}{|c|}{ Wilayah Barat } & \multicolumn{2}{|c|}{ Wilayah Tengah } & \multicolumn{2}{|c|}{ Wilayah Timur } & \\
\hline & Kecil & Sedang & Besar & Kecil & Sedang & Kecil & Sedang & \\
\hline $\mathrm{a}$ & 3 & 5 & & 9 & 7 & 3 & 1 & 28 \\
\hline $\mathrm{b}$ & 7 & 4 & 1 & 16 & 4 & 13 & 6 & 51 \\
\hline $\mathrm{c}$ & 2 & & & 1 & & 4 & & 7 \\
\hline $\mathrm{d}$ & & & & & & 1 & & \\
\hline $\mathrm{e}$ & 1 & & 1 & 4 & 2 & 9 & 2 & 19 \\
\hline $\mathrm{f}$ & & & & 1 & & 1 & & 2 \\
\hline $\mathrm{g}$ & 3 & & & & & & & 3 \\
\hline $\mathrm{h}$ & & & & 1 & & 4 & & 5 \\
\hline $\mathrm{i}$ & & & & 2 & & & & 2 \\
\hline $\mathrm{j}$ & & & & & & & 1 & 1 \\
\hline $\mathrm{k}$ & & & & & & 5 & & 5 \\
\hline 1 & & & & & 2 & & & 2 \\
\hline
\end{tabular}

Keterangan: = lokasi sampel

Tabel 6. Sebaran jumlah informan

\begin{tabular}{|c|c|c|c|c|c|c|c|}
\hline \multirow{3}{*}{ Tipe Permukiman } & \multicolumn{7}{|c|}{ Jumlah Responden } \\
\hline & \multicolumn{3}{|c|}{ Wilayah Barat } & \multicolumn{2}{|c|}{ Wilayah Tengah } & \multicolumn{2}{|c|}{ Wilayah Timur } \\
\hline & Kecil & Sedang & Besar & Kecil & Sedang & Kecil & Sedang \\
\hline a & 1 & 3 & & 1 & 3 & 1 & \\
\hline $\mathrm{b}$ & 1 & & 5 & 2 & 3 & 1 & 3 \\
\hline c & 1 & & & & & & \\
\hline d & & & & & & 1 & \\
\hline $\mathrm{e}$ & 1 & & & 1 & & & 3 \\
\hline $\mathrm{f}$ & & & & 1 & & & \\
\hline g & 1 & & & & & & \\
\hline $\mathrm{h}$ & & & & & & 1 & \\
\hline $\mathrm{i}$ & & & & 1 & & & \\
\hline $\mathrm{j}$ & & & & & & & 1 \\
\hline $\mathrm{k}$ & & & & & & 1 & \\
\hline 1 & & & & & 1 & & \\
\hline
\end{tabular}


Sebaran dan jumlah poligon yang mewakili masingmasing tipe permukiman kemudian dijadikan sebagai dasar stratifikasi permukiman untuk penentuan lokasi sampel dan jumlah informan sebagaimana tercantum pada Tabel 5 dan Tabel 6.

Berdasarkan tabulasi jumlah dan ukuran poligon dari tiap tipe permukiman pada Tabel 5 dan 6 , penulis menentukan lokasi sampel di tiap wilayah pelayanan Dinas Kebersihan dan Pertamanan Kota Tangerang dengan sebaran serta jumlah informan untuk wawancara dan penyebaran kuesioner sesuai metode yang telah disampaikan di atas.

Hasil kuesioner dan wawancara langsung di lapangan dapat dilihat pada Tabel 7. Tipologi permukiman akhir yang menggambarkan karakter permukiman dan masyarakatnya dalam menangani sampah dapat dilihat pada Tabel 8 dengan sebarannya seperti dapat dilihat pada Gambar 1 .

Tabel 7. Karakter masyarakat tiap tipe permukiman

\begin{tabular}{|c|c|c|c|c|c|c|c|}
\hline Tipe Permukiman & Pemilahan & Partisipasi & Penerimaan & Kesanggupan & Kemauan & Kader & Pengelola \\
\hline $\mathrm{a}$ & T Ada & Rendah & $\mathrm{T} \mathrm{M}$ & Lebih & $\mathrm{M}$ & T Ada & Ada \\
\hline $\mathrm{b}$ & T Ada & Rendah & $\mathrm{M}$ & Sesuai & M & Ada & Ada \\
\hline $\mathrm{c}$ & T Ada & Rendah & M & Sesuai & M & T Ada & T Ada \\
\hline $\mathrm{d}$ & T Ada & Rendah & M & Lebih & M & $\mathrm{T}$ Ada & T Ada \\
\hline e & T Ada & Rendah & $\mathrm{T} \mathrm{M}$ & Sesuai & M & T Ada & Ada \\
\hline $\mathrm{f}$ & T Ada & Rendah & $\mathrm{T} \mathrm{M}$ & Sesuai & M & T Ada & T Ada \\
\hline $\mathrm{g}$ & T Ada & Rendah & $\mathrm{T} \mathrm{M}$ & Lebih & M & T Ada & Ada \\
\hline $\mathrm{h}$ & T Ada & Rendah & T M & Sesuai & M & $\mathrm{T}$ Ada & T Ada \\
\hline i & T Ada & Rendah & $\mathrm{T} \mathrm{M}$ & Sesuai & M & T Ada & T Ada \\
\hline $\mathrm{j}$ & T Ada & Rendah & M & Sesuai & M & T Ada & T Ada \\
\hline $\mathrm{k}$ & T Ada & Rendah & $\mathrm{T} \mathrm{M}$ & Sesuai & M & T Ada & Ada \\
\hline 1 & T Ada & Rendah & $\mathrm{T} \mathrm{M}$ & Sesuai & $\mathrm{M}$ & T Ada & Ada \\
\hline
\end{tabular}

Keterangan: $\mathrm{T}=$ tidak, $\mathrm{M}=$ mau

Tabel 8. Tipologi permukiman

\begin{tabular}{|c|c|c|c|c|c|c|c|c|c|c|}
\hline $\begin{array}{c}\text { Tipologi } \\
\text { Permukiman }\end{array}$ & $\begin{array}{c}\text { Kelompok } \\
\text { Permukiman }\end{array}$ & $\begin{array}{c}\text { Ketersediaan } \\
\text { Lahan }\end{array}$ & Aksesibilitas & Pemilahan & Partisipasi & Penerimaan & Kesanggupan & Kemauan & Kader & Pengelola \\
\hline $\mathrm{A}$ & 2 & T A & Md & T Ada & Rendah & $\mathrm{M}$ & Sesuai & $\mathrm{M}$ & Ada & Ada \\
\hline $\mathrm{B}$ & 1 & $\mathrm{TA}$ & $\mathrm{T} \mathrm{Md}$ & T Ada & Rendah & M & Sesuai & M & T Ada & T Ada \\
\hline $\mathrm{C}$ & 2 & $\mathrm{TA}$ & $\mathrm{T} \mathrm{Md}$ & T Ada & Rendah & $\mathrm{T} \mathrm{M}$ & Sesuai & M & T Ada & T Ada \\
\hline D & 1 & T B & $\mathrm{Md}$ & T Ada & Rendah & $\mathrm{M}$ & Lebih & M & T Ada & T Ada \\
\hline $\mathrm{E}$ & 3 & T B & Md & T Ada & Rendah & $\mathrm{M}$ & Sesuai & M & T Ada & T Ada \\
\hline $\mathrm{F}$ & 1 & T B & Md & T Ada & Rendah & $\mathrm{T} \mathrm{M}$ & Lebih & M & T Ada & Ada \\
\hline G & 2 & T B & Md & T Ada & Rendah & $\mathrm{T} \mathrm{M}$ & Sesuai & M & T Ada & Ada \\
\hline I & 1 & T B & $\mathrm{T} \mathrm{Md}$ & T Ada & Rendah & $\mathrm{T} \mathrm{M}$ & Lebih & M & T Ada & Ada \\
\hline $\mathrm{J}$ & 3 & T B & $\mathrm{T} \mathrm{Md}$ & T Ada & Rendah & $\mathrm{T} \mathrm{M}$ & Sesuai & M & T Ada & T Ada \\
\hline $\mathrm{K}$ & 2 & $\mathrm{~T} \mathrm{~T}$ & Md & T Ada & Rendah & $\mathrm{T} \mathrm{M}$ & Sesuai & M & T Ada & Ada \\
\hline $\mathrm{L}$ & 2 & T B & $\mathrm{T} \mathrm{Md}$ & T Ada & Rendah & $\mathrm{T} \mathrm{M}$ & Sesuai & M & T Ada & Ada \\
\hline
\end{tabular}

Keterangan: $\mathrm{TA}=$ bisa langsung dimanfaatkan, $\mathrm{TB}=$ pemanfaatan perlu negosiasi, $\mathrm{TT}=$ tidak tersedia lahan, $\mathrm{T}=$ tidak, $\mathrm{Md}=$ memadai, $\mathrm{M}=$ mau

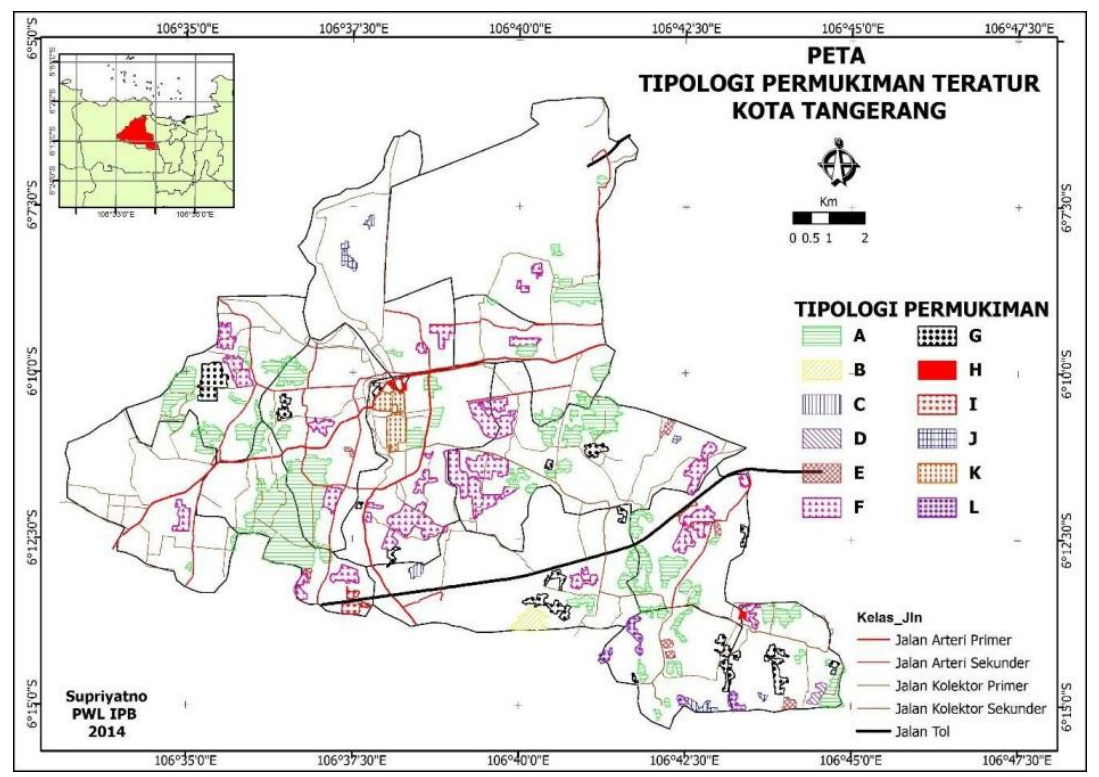

Gambar 1. Peta tipologi permukiman Kota Tangerang 


\section{Sebaran Sarana Persampahan}

Berdasarkan persepsi stakeholder yang menjadi responden AHP didapatkan bahwa, faktor penerimaan masyarakat terhadap pengelolaan sampah di lingkungan mereka menjadi kriteria yang sangat berpengaruh terhadap penentuan jenis sarana persampahan yang sesuai yaitu dengan bobot sebesar $17.1 \%$, sedangkan kriteria yang dianggap tidak begitu berpengaruh adalah faktor keberadaan pengelola yang hanya mempunyai bobot $7.9 \%$. (Tabel 9).

Pada tipologi permukiman yang mempunyai karateristik yang sesuai dengan pedoman umum 3R, maka alternatif sarana TPST dan/atau sarana 3R diberikan ranking yang lebih tinggi (ranking 1 dan/atau 2) dibandingkan alternatif kontainer (ranking 2 dan/atau 3) dan begitu sebaliknya. Hasil analisis AHP tersebut kemudian digunakan sebagai nilai pembobotan masingmasing kriteria pada analisis MCDM-TOPSIS untuk mendapatkan prioritas sarana sampah yang sesuai pada setiap tipologi permukiman.

Tabel 9. Hasil AHP

\begin{tabular}{ll}
\hline \multicolumn{1}{c}{ Faktor } & Bobot \\
\hline Penerimaan & $17.1 \%$ \\
Ketersediaan Lahan & $13.3 \%$ \\
Partisipasi & $11.2 \%$ \\
Aksesibilitas & $11.0 \%$ \\
Kemauan membayar & $10.9 \%$ \\
Kesanggupan membayar & $9.7 \%$ \\
Keberadaan kader & $9.5 \%$ \\
Pemilahan sampah & $9.3 \%$ \\
Keberadaan pengelola & $7.9 \%$ \\
\hline
\end{tabular}

Tabel 10. Sarana persampahan prioritas

\begin{tabular}{ccccccc}
\hline & \multicolumn{7}{c}{ PRIORITAS SARANA } \\
TIPOLOGI & ALT. & R.U.V & ALT. & R.U.V & ALT. & R.U.V \\
\cline { 2 - 7 } & & & & & \\
\hline A & TPST & $\mathbf{0 . 7 6}$ & Sarana 3R & 0.39 & Kontainer & 0.35 \\
B & TPST & $\mathbf{0 . 7 0}$ & Sarana 3R & 0.41 & Kontainer & 0.41 \\
C & Kontainer & $\mathbf{0 . 5 6}$ & TPST & $\mathbf{0 . 5 0}$ & Sarana 3R & 0.41 \\
D & Kontainer & $\mathbf{0 . 5 9}$ & Sarana 3R & $\mathbf{0 . 5 2}$ & TPST & $\mathbf{0 . 5 1}$ \\
E & TPST & $\mathbf{0 . 5 7}$ & Kontainer & $\mathbf{0 . 5 1}$ & Sarana 3R & $\mathbf{0 . 4 8}$ \\
F & Kontainer & $\mathbf{0 . 7 7}$ & Sarana 3R & 0.36 & TPST & 0.33 \\
G & Kontainer & $\mathbf{0 . 6 8}$ & Sarana 3R & 0.43 & TPST & 0.41 \\
H & Kontainer & $\mathbf{0 . 7 4}$ & Sarana 3R & 0.48 & TPST & 0.34 \\
I & Kontainer & $\mathbf{0 . 7 0}$ & Sarana 3R & 0.40 & TPST & 0.38 \\
J & Kontainer & $\mathbf{0 . 6 8}$ & Sarana 3R & 0.51 & TPST & 0.39 \\
K & Kontainer & $\mathbf{0 . 5 6}$ & Sarana 3R & 0.47 & TPST & 0.38 \\
L & Kontainer & $\mathbf{0 . 5 4}$ & Sarana 3R & $\mathbf{0 . 5 0}$ & TPST & 0.42 \\
\hline
\end{tabular}

Keterangan : ALT $=$ alternatif sarana, R.U.V = Range Unit Value

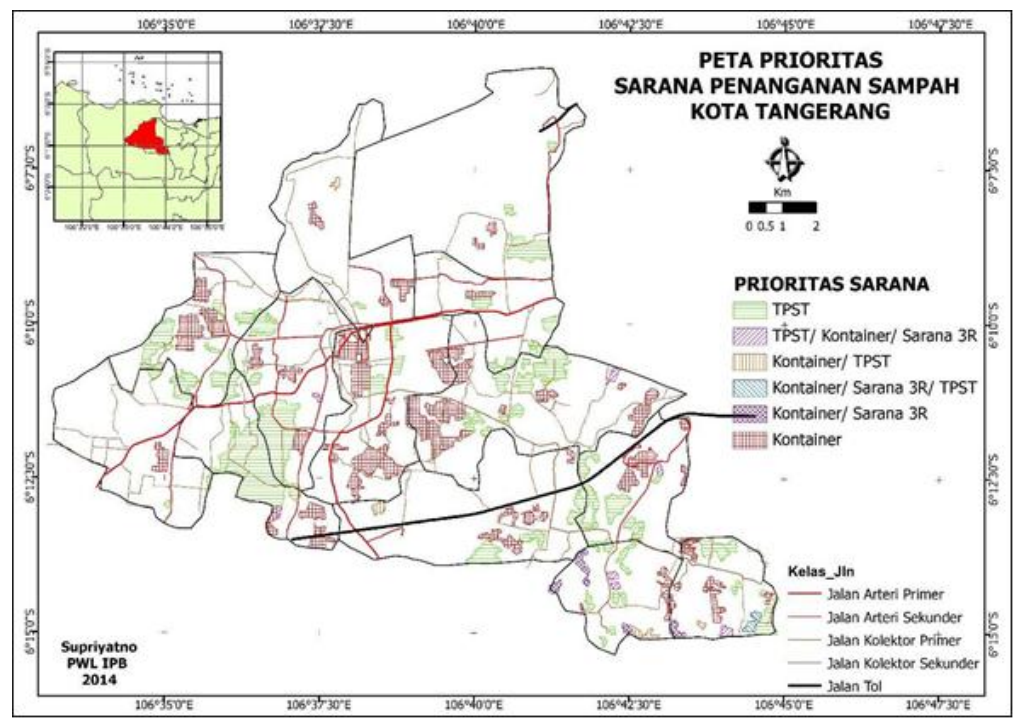

Gambar 2. Peta sebaran prioritas sarana persampahan Kota Tangerang 
Dari hasil sintesis AHP dan MCDM-TOPSIS terdapat 6 kelompok permukiman sebagaimana tercantum pada Tabel 10 dengan sebaran prioritas sarana penanganan sampah pada masing-masing tipologi permukiman di Kota Tangerang dapat di lihat pada Gambar 2.

Tipologi permukiman berdasarkan prioritas sarana penanganan sampah (1) permukiman yang sarana prioritasnya hanya TPST yaitu tipe A dan B, (2) permukiman dengan prioritas sarananya TPST, kontainer, dan sarana 3R adalah tipe E, (3) permukiman yang prioritas sarananya kontainer dan sarana $3 \mathrm{R}$ adalah tipe $\mathrm{L}$, (4) permukiman dengan prioritas sarananya kontainer, sarana 3R dan TPST adalah tipe D, (5) permukiman yang mempunyai prioritas sarana kontainer dan TPST adalah tipe C, dan (6) permukiman yang prioritasnya hanya kontainer yaitu tipe F, G, H, I, J, dan K.

\section{SIMPULAN}

Berdasarkan hasil analisis yang telah dilakukan pada penelitian ini, dapat disimpulkan:

1. Terdapat 12 tipologi permukiman berdasarkan karakteristik fisik lingkungan dan karakter masyarakat dalam mengelola sampah, dari yang paling memenuhi kriteria pedoman umum pengelolaan sampah terpadu 3R berbasis masyarakat sampai yang kurang memenuhi kriteria, yaitu tipologi A, B, C, D, E, F, G, H, I, J, K dan L.

2. Terdapat 6 kelompok permukiman berdasarkan prioritas jenis sarana sampah yaitu : (1) permukiman yang sarana prioritasnya hanya TPST, (2) permukiman dengan prioritas sarananya TPST/ kontainer/sarana 3R, (3) permukiman yang prioritas sarana nya adalah kontainer atau sarana 3R, (4) permukiman yang mempunyai prioritas sarana kontainer/sarana 3R/ TPST, (5) permukiman yang prioritasnya kontainer atau TPST, dan (6) permukiman yang prioritasnya hanya kontainer sampah.

\section{DAFTAR PUSTAKA}

Departemen Pekerjaan Umum. 2008. Buku Pedoman 3R Berbasis Masyarakat di Kawasan Permukiman. Departemen Pekerjaan Umum. Jakarta.

Eriyatno dan F. Sofyar. 2007. Riset Kebijakan: Metode Penelitian untuk Pascasarjana. IPB Press. Bogor.

Hwang, C.L. and K. Yoon. 1981. Multiple Attribute Decision Making: Methods And Applications. Springer. Berlin.

[JWMC] Jabodetabek Waste Management Consultant. 2005. Rencana Pengelolaan Persampahan Kota Tangerang. Departemen Pekerjaan Umum. Jakarta.

Pemerintah Republik Indonesia. 2012. Peraturan Pemerintah No 81 Tahun 2012 tentang Pengelolaan Sampah Rumah Tangga dan Sampah Sejenis Rumah Tangga. Pemerintah Republik Indonesia. Jakarta.

Postorino, M.N. and F.G. Pratico. 2012. An application of multi-criteria decision-making analysis to a regional multi-airport system. Research In Transportation Business \& Management, 4: 44-52.

Saaty, T. 2008. Making decisions in hierarchic and network systems. Int. J. Applied Decision Sciences, 1: 24-79.

Saribanon, N.E. Soetarto, S.H. Sutjahjo, E.G. Sa'id, dan Sumardjo. 2007. Pendekatan tipologi dalam pengembangan partisipasi masyarakat (studi kasus: pengelolaan sampah permukiman berbasis masyarakat di Kotamadya Jakarta Timur). Jurnal Teknik Lingkungan, 8: 235-244.

Shih, H., H. J. Shyur, and E.S. Lee. 2007. An extension of TOPSIS for group decision making. Mathematical and Computer Modelling, 45: 801-813. 